DOI: https://doi.org/10.15407/preislamic2021.02.089

UDC 94(397)

\title{
ROLE OF THE AFRICAN CAVALRY IN THE BARCID ARMY
}

\author{
A. I. Kozak \\ $\mathrm{PhD}$ (History) \\ Independent Researcher \\ citizen.of.carthage@gmail.com
}

The article analyzes the cavalry detachments, which consisted of the inhabitants of Africa, both directly from the subjects of Carthage, and from the tribes allied to the Punics, who formed the core of the Barcid army during the Second Punic War (218-201 BC) and played a decisive role in the most major battles, the Libyphoenicians and Numidians. Such aspects as tactics, weapons, the status of horsemen associated with the above-mentioned military formations are considered. It is argued that despite the widespread stereotype of the Numidians and Libyphoenicians as mercenaries, they fought on a voluntary basis. On the one hand, this provided them with a high fighting spirit and motivation, and on the other, they, like any militia, operated only near the territories of their settlement, going on long military campaigns only in small numbers. Attention is paid to the peculiarities of the armament of the African cavalry. Among the Libyphoenicians, this was the Hellenistic manner with chain mail or cuirass, spear and shield. The Numidians used chitons and leather carapaces over which they wore cloaks, and the Thyreos - medium-sized round leather shields. The main offensive weapon of the Numidians was javelins, made entirely of wood, with iron laurel tips. It is proved that due to its set of weapons and professional training, the African cavalry was a universal type of troops. The Carthaginians used it for reconnaissance, foraging, exhausting the enemy and striking at decisive moments of the battle. Not a single military campaign of the Barcids was complete without the participation of these horsemen, who, despite popular belief, were not classic mercenaries, but associated with their commanders by personal loyalty.

Keywords: Carthage, Second Punic War, Hannibal, Numidians, Libyphoenicians, Hellenism, Art of war, weapons, tactics

\section{A. I. Козак}

\section{РОЛЬ АФРИКАНСЬКОЇ КАВАЛЕРІЇ В АРМІЇ БАРКІДІВ}

Загони, що складалися із жителів Африки, як безпосередньо з підданих Карфагена, так із союзних пунійцям племен, формували ядро армії Баркідів під час Другої Пунічної війни (218-201рp. до н. е.) й відіграли вирішальну роль у більшості визначних битв. Проте значна кількість аспектів, таких як тактика, озброєння, статус, пов'язаних зі згаданими військовими формуваннями, особливо кавалерійськими, на сьогоднішній день залишаються контроверсійними і потребують більш детального дослідження.

Як свідчить Полібій, у 218 р. до н. е., перед початком Другої Пунічної війни

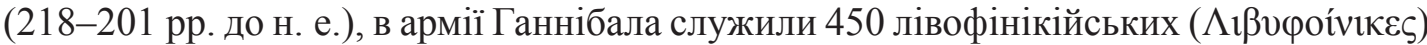
і лівійських вершників, які розміщувались в Іспанії (Pol., III.33.15). Тіт Лівій стверджує, що цей загін складався суто з лівофінікійців (Liv., XXI.22.3). Дані про участь лівофінікійців в італійському поході Ганнібала відсутні, проте, враховуючи, що настільки значна їх кількість перебувала в Іспанії перед початком воєнної кампанії проти Риму, цілком імовірно, що вони пересікли Альпи разом з Баркою. 
Тіт Лівій описує лівофінікійців як етнос, який з'явився після змішання пунійців та африканців (Liv., XXI.22.3), однак це припущення здається надто спрощеним [Лансель 2002, 288; Walbank 1957, 363; Warmington 1964, 55]. Більш достовірною видається версія Діодора Сицилійського, який називає лівофінікійців мешканцями заснованих свого часу фінікійцями приморських міст: Утіки, Гіппо Заріта, Гадруме-

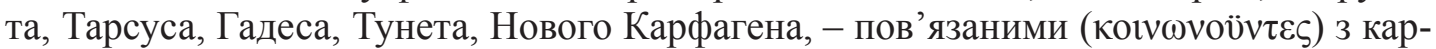

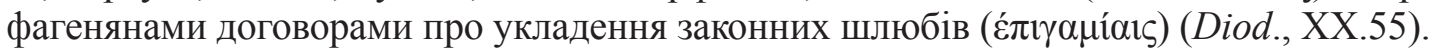

Лівофінікійці підпорядковувалися тим же законам, що й карфагеняни, проте мали сплачувати мито і служити у війську, тоді як пунійці звільнялися від таких повинностей (Pol., VII.9.5) [Lazenby 1996, 24; Warmington 1964, 70-72].

У нас немає даних джерел про те, що ці воїни буди найманцями [Циркин 2001, 428; Healy 1994, 20]. Вони воювали на добровільних засадах. 3 одного боку, це забезпечувало їм високий бойовий дух та мотивацію, а з другого - вони, як і будь-яке ополчення, діяли переважно поблизу своїх міст, лише в невеликій кількості вирушаючи у тривалі воєнні походи. Напевне, саме тому в часи Пунічних війн лівофінікійці згадуються в джерелах здебільшого під час битв на півночі Африки та півдні Іберії й значно менше в Італії.

Полібій, описуючи битву при Требії (218 р. до н. е.), розрізняє нумідійців та “стриману і стійку” кінноту (Pol., III.65.6), якою могли бути лише лівофінікійці з Icпанії. Отже, лівофінікійська кіннота в італійській армії Ганнібала була “важкою”, на відміну від нумідійських вершників.

Як були озброєні лівофінікійські кавалеристи, наразі остаточно не визначено, але, судячи з Лівієвого опису сутички карфагенської кінноти з іберійським племенем ваккеїв (219 р. до н. е.), це була елліністична манера з кольчугою або кірасою, списом та щитом [Snodgrass 1997, 119-123].

Щодо цього інциденту, Лівій пише, що “піхотинці і без того ледь могли стояти і навіть на мілкому місці насилу перебирали ногами, так що й беззбройний вершник ненавмисним поштовхом коня міг збити їх з ніг; вершник, навпаки, вільно маючи у своєму розпорядженні і зброю, і власне тіло, сидячи на коні, впевнено рухався навіть серед безодні й тому міг вражати і далеких, і близьких" (Liv., XXI.5.14).

Єдине достеменне археологічне зображення лівофінікійського вершника, яке $\epsilon$ в нашому розпорядженні, - північноафриканська теракотова статуетка. Вона зображує вершника одягненого в елліністичну “мускулисту” кірасу та озброєного двома легкими списами, 3 круглим щитом із закругленим умбоном. На шиї він носить півмісяць, що деякі дослідники вважають ознакою присвяти цього вершника богині Астарті [Hoyos 2010, 42].

Археологи відшукали поблизу руїн Карфагена велику кількість списів, які можна зіставити з македонськими ксістонами. Використовувалася така зброя лише кавалерією. Розмір древка списів був доволі незначним. Виготовлялися вони 3 кизилового дерева та оснащувалися широкими залізними наконечниками й втоками, які давали змогу вершнику в разі пошкодження списа продовжувати бій за допомогою іншої половини. Зброя трималася не напереваги, а підіймалася для завдавання удару згори [Head 1982, 143].

Напевне, такі вершники використовували меч, коли відкидали свої списи, й ідеальним вибором, згідно із Ксенофонтом, був вигнутий грецький копіс (колі $)$ (Xen., Eq. 12.11) [Snodgrass 1997, 97, 109]. 
Лівофінікійці використовували кавалерійські бронзові каски “беотійського" типу. Завдяки формі такого шолома, яка не демаскувала вершника, їм часто вдавалося організувати засідку під час бою. Наприклад, у битві при Требії у 217 р. до н. е., коли 500 африканських вершників сховалися в рові і зуміли завдати удар у вирішальний момент (Pol., III.65.6).

Під час відкритого бою, як можна судити з відомостей Поліена і Лівія, лівофінікійська кавалерія шикувалася декількома лініями, що налічували по 450 вояків [Daily 2008, 168]. Такий порядок давав змогу ефективно командувати цим контингентом, що, найімовірніше, було спрямовано на поступове введення в битву частин кінноти. Саме через таку організацію ця кавалерія часто рятувала розташовані порядки власної піхоти, прикриваючи їхній відхід та даючи можливість перегрупуватися, як під час низки битв іберійської кампанії 215 р. до н. е., наприклад битви біля Ібера (Liv., XXIII.24.6-13).

Пересувався цей вид кавалерії від одного опорного пункту до іншого за допомогою форсованих маршів. Причому дотримувалися не загального строю, а переміщувались розрізненими ескадронами по 64 вершники. Деякі дослідники пов'язують такий спосіб руху з наслідками реформування кавалерії саме Ганнібалом Баркою [Денисон 2001, 23]. Саме ескадронна побудова бойового порядку дала змогу карфагенській кінноті здійснювати ефективні атаки на ворожі колони та комунікації, прориваючи їх у декількох місцях одночасно. Причому це було характерно для них аж до зруйнування Карфагена. У часи Третьої Пунічної війни (149146 pp. до н. е.) такий прийом застосовував полководець Карфагена Гімількон Фамея (App., Lib. 130).

Також варто зазначити, що лівофінікійці могли обіймати найвищі командні посади в армії Баркідів. Наприклад, у 212-210 рр. до н. е. нумідійською кіннотою, що воювала на Сицилії, командував представник цього етносу, якого Лівій називає Муттін (Muttines) і який був уродженцем Гіппакріта (Liv., XXV.40.5). Він описується як досвідчений воїн, якого Ганнібал навчив військового мистецтва [Walbank 1957, 150; Hoyos 2019, 18], з чого стає зрозуміло, що Барка довіряв йому, оскільки призначив на настільки важливу посаду.

Муттін доволі успішно діяв на Сицилії, проте через намір свого командира Ганнона змістити його перейшов на бік римлян, був представлений сенату, отримав римське громадянство і навіть у 190 р. до н. е. був командиром римського авангарду під час Антіохової війни.

Отже, лівофінікійці становили командний корпус середньої ланки для армії Карфагена, а також формували окремі загони для завдавання удару у вирішальні моменти бою.

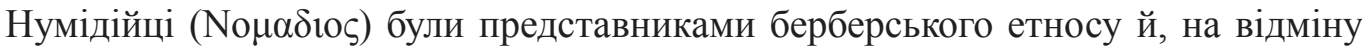
від сусідніх лівійських племен, займалися кочовим скотарством, а не землеробством [Brett, Fentress 1996, 24-26; Лансель 2002, 158]. Нумідійці часто зображуються в античних джерелах доволі стереотипно, незважаючи на те що чимало авторів вказують на їхню витривалість на полі бою (Pol., III.71.10; App., Pun. 11.71; Plin., Nat. Hist. 5.1), вони ж називають африканських вершників “боягузами", що схильні до втечі з поля бою, який складається не на їх користь (Pol., I.47.7). Лівій зображує нумідійців неблагонадійними, недисциплінованими, запальними і більш жадібними, ніж будь-які інші варвари (Liv., XXV.41.4, XXVIII.44.5, XXIX.23.4, XXX.12.18). 
Нумідійська кіннота брала участь в усіх без винятку визначних битвах за участю армії Баркідів і часто відігравала в них провідну роль. Саме завдяки цим вершникам Ганнібал дістав змогу протягом тривалого часу діяти на ворожій території. Нумідійці не були єдиним народом, а проживали на території двох царств (масесіли - на заході та масіли - на сході), прилеглих до земель Карфагена, а також під владою багатьох місцевих правителів.

Хоча традиційно нумідійців вважають найманцями [Griffith 1935, 240; Козак $2010,260]$, таке твердження є хибним. Африканські племена йшли на службу до Карфагена, а згодом і до Риму як союзні загоні, які воювали не за платню, а за вагому частку трофеїв. Те, що бербери не були найманцями в традиційному значенні цього слова, підтверджує система командування такими військами. Вони обирали зі свого складу не лише командирів нижчої та середньої ланки, а й навіть командувачів цілого контингенту, що взагалі не було характерно для пунійської військової системи. Наприклад, майбутній цар Массініса командував нумідійцями в битвах при Бекулі та Замі (App., Lib. 40), а цар Сіфакс - у битві на Великих рівнинах (Liv., XXX.11.2). Подібний статус мали в армії Баркідів вожді Наравас (Pol., I.78.1-11) та Тіхей (Pol., XV.3.5) [Lopez-Sanchez 2010, 30].

Характерно, що Аппіан називає кількох нумідійських вождів карфагенської армії, які очолювали кавалерію в битві при Замі (App., Pun. 33.44), хоча під час італійської кампанії вершники служили під керівництвом Ганнібала, а в Іспанії - Газдрубала та Гамількара. Можна припустити, що під час тривалої служби в армії Баркідів вони переходили з підданства своїх царів до карфагенських полководців [Griffith 1935, 227; Fields 2011, 19]. Така сама ситуація спостерігалася й серед загонів лівійської піхоти, проте для нумідійців зв'язок між полководцем і воїнами міг зміцнюватися шлюбними зв'язками. Наприклад, під час Лівійської війни (240238 рр. до н. е.) союзний Карфагену нумідійський принц Наравас був заручений 3 дочкою Гамількара (Pol., I. 78.8-9).

Нумідійців під Каннами очолював один із карфагенських соратників Ганнібала Ганнон (Pol., III.114.7) або Махарбал (Liv., XXII.46.7), а на Сицилії, як зазначено вище, ними командував лівофінікієць Муттін. Очевидно, що вони керували етнічними, фактично племінними контингентами, а не сформованими за певною системою військовими загонами [Gsell 1928, 391].

Легка африканська кіннота, згідно зі свідченнями Кріспа взагалі не мала певної організаційної структури й “групувалася в зграї по декілька вояків” (Crisp., Jug. 94.1). Однак Лівій у низці випадків згадує нумідійців, які воюють, будучи організованими в турми (turmae) (Liv., XXV.17.3; XXVII.26.8). Хоча античний автор, імовірно, не мав на увазі ескадрони чисельністю 30 вершників, як у римській армії, можна припустити, що нумідійці організовувалися в загони чисельністю кілька сотень осіб, значно менші за племінні групи. Аналізуючи Полібія, можна припустити, що Ганнібалу вдалось утворити з них організовані військові формування на зразок елліністичних пельтастів, які нараховували 140 вояків [Fuchs 1894, 255].

На марші нумідійці діяли декількома “зграями”, переважно в авангарді власних військ. Це давало їм змогу виконувати цілу низку завдань, зокрема вести розвідку, при можливості брати полонених та унеможливлювати раптовий напад кінних роз'їздів противника на лави піхоти. Наприклад, нумідійці вчасно виявили в 218 р. до н. е. війська Сципіона поблизу Массалії (Pol., III.44.3), а саме цим був 
продиктований Ганнібалів вибір шляху через Альпи. Крім того, при переходах нумідійські вершники стежили за порядком у колонах решти армії (Liv., XXIV.12.4), організовували подолання водних та затоплених перешкод (Pol., III.55.8).

При пересуванні легка африканська кавалерія не дотримувалася певного порядку, а нещільними масами переміщувалась перед фронтом та в тилу колон важкоозброєних загонів (Plut., Tim.8). Перевага таких маршів виявлялася в суттєвому збільшенні площі огляду застрільників, які могли вчасно помітити ворога й нав'язати йому бій, одночасно захищаючи шикування власної піхоти [Bagnall 1991, 8]. Часто африканці займали та обороняли декілька пагорбів попереду головних військ, відтягуючи ворожі сили на себе, а також загрожуючи флангам противника в разі його наступу.

Типовим для легкої африканської кінноти було влаштування засідок на місцевості. Традиційно їх поділяють на два види. Яскравий вияв першого спостерігається в битві при Требії (Jug., XXII.48.2). Численний загін нумідійців зайняв позицію поблизу поля бою в яру та заліг. У вирішальний момент кіннотники завдали удар по флангу й тилу римського війська. Полібій вважає, що головним для успіху такої тактичної хитрості є “надійне приховування мечів, щитів, дротиків, тобто предметів, які можуть видати засідку блиском або характерною формою” (Pol., III.72). А Фронтін запевняє, що під час нальотів нумідійці намагалися збільшити ефект, спричинений несподіванкою, "роблячи потворні гримаси та загрозливо волаючи" (Front., I.5.16).

Інший вид засідки продемонстрований при переправі через річку Родан (Pol., III.43) та під час атаки вершників Массініси на табір Газдрубала Козла у 202 р. до н. е. (Liv., XXX.6). Два-три загони нумідійців розташовувались на далекій відстані від місця бою і після подачі сигналу починали стрімкий рух у бік поля битви, створюючи ілюзію значного підкріплення та небезпеки оточення. Цей своєрідний “трюк” часто спричиняв паніку та безладну метушню серед ворожих лав.

У відкритих битвах нумідійці розташовувались на фланзі, при Каннах та Замі, або перед фронтом шикування, наприклад біля Бекули у 208 р. до н. е. (Pol., XI.39). Майже завжди перед легкими африканськими вершниками ставилося завдання спровокувати противника на атаку і відволікти його примарним відступом з метою змусити залишити вигідну позицію. Полібій називає примарний відхід та швидке повернення й повторну атаку "найхарактернішою тактикою нумідійців, яка сковувала противника, не даючи йому змоги просунутися вперед” (Pol., XIV.1).

Однак найкращі якості африканських кочовиків виявлялися під час переслідування ворога, який уже розладнав свої бойові шикування. Полібій стверджує, що саме в такій ролі вони “незамінні й найкращі” (Pol., III.116.6). Коли при Каннах ворог був дезорганізований атакою важкої кавалерії, а при Замі - слонами, саме нумідійці кидалися йому навздогін. Судячи із зображення на колоні Траяна, у разі переслідування нумідійці намагались не вбивати втікачів, а хапали їх за волосся та зв’ язували [Salmon 1960, 123].

Типовим для нумідійців було створення своєрідних “загонів смерті”, які полювали на ворожих воєначальників [Walsh 1965, 152; Козак 2010, 260]. Ці підрозділи, наприклад, убили римських полководців Марцелла (App., Hann.50), Гракха (Liv., XXV.16), поранили Сципіона та Массінісу (Аpp., Lib.50).

Отже, завдяки чудовій підготовці та арсеналу різноманітних тактичних прийомів легка африканська кіннота була доволі універсальним і мобільним видом військ. 
Карфагенські полководці використовували ії переважно для розвідки, фуражування, засідок, виснаження та переслідування противника. Жодна воєнна кампанія пунійців не обходилася без участі цих вправних вершників.

Намагання нумідійської кавалерії не вступати в рукопашний бій диктувалося іiї слабкою захищеністю та непридатністю для такого виду бою їхніх невеликих коней породи “бородаті нумідійці" [Hyland 1990, 12; Андерсон 2006, 19; Конноли 2001, 149]. Підтвердження цієї гіпотези можна знайти в праці Фронтіна, який зневажливо відгукується про бойові якості нумідійських коней (Front., III.8.277).

Отже, нумідійські коні були маленькими витривалими поні. На колоні Траяна африканські кіннотники зображені верхи на невеликих тваринах. Лівій висміює зовнішній вигляд цих коней, підкреслюючи, що через їхній розмір та худорлявість нумідійці мали демонструвати надзвичайні навички верхової їзди (Liv., XXXV.11.611). Такої самої думки дотримується і Страбон, якого дивує швидкість коней настільки невеликого розміру (Strab., XVII.3.7).

Щодо захисного обладунку легких африканських вершників, то Гай Саллюстій Крісп твердить про “повну його відсутність” (Crisp., Jug. 94.1), але Страбон згадує використання нумідійцями хітонів та шкіряних панцирів, поверх яких надягалися плащі. Його слова підтверджуються барельєфами на колоні Траяна, де нумідійці зображені в плащах і хітонах [Lazenby 1978, 36; Конноли 2001, 149-151].

Натомість Лівій, описуючи битву під Каннами, вказує на металеві нагрудники нумідійців (Liv., XXII.48.2). Аналізуючи ці свідчення, можна припустити, що Ганнібал переозброїв частину своїх нумідійців трофейними латами, імовірно - тридисковими бронзовими пластинами римо-італійської кінноти, які кріпилися шкіряними ремінцями та захищали не лише груди, а й спину воїнів [Bagnall 1991, 8]. Перевагою цих лат було забезпечення свободи руху для метання дротиків.

Про шоломи нумідійських вершників немає ані письмових, ані археологічних відомостей.

Крісп та Страбон пишуть про широке використання нумідійськими вершни-

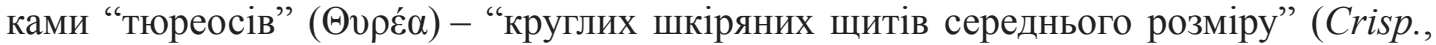
Jug.94.1; Strab., XVI.10.14). Судячи із зображень на монументах поблизу Тунета, діаметр тюреоса сягав 70-80 см. Характерними рисами $є$ відсутність умбона та ліктьовий хват. Аппіан повідомляє, що матеріалом для виготовлення подібного щита правила дерев'яна основа, вкрита слоновою шкірою, хоча деякі дослідники вважають, ніби тюреос міг бути й просто шкіряним [Алексинский, Жуков Бутягин, Коровкин 2005, 73]. Під час їзди вершник мав змогу закидати його за спину за допомогою спеціального ремінця.

Головною наступальною зброєю нумідійців Крісп називає довгий дротик, цілковито виготовлений із дерева (Crisp., Jug.50.4). Протилежні дані подає Страбон, який акцентує маленьку довжину і залізний наконечник африканського дротика (Strab., XVI.10.13), що підтверджується знахідками в Північній Африці низки залізних лавролистих наконечників та втоків списів [Bradford 2001, 222]. Їхня довжина була доволі незначною (до 1,2 м), а тонкий наконечник кріпився до древка за допомогою двох втулок. Підток призначався для обмеження рухів ворога в разі влучання дротика в щит або броню. Незважаючи на велику разючу силу зброї, кинути ії можна на доволі коротку відстань, тому цілком імовірно, що для дальнього метання використовувався дротик, описаний Кріспом. 
Лівій наводить приклад озброєння нумідійців “короткими двобічно загостреними кинджалами" (Liv., XVI.10.14). Схожі мечі знайдені в нумідійських похованнях північніше Хемту [Head 1982, 171]. Вони мають пряму форму, загострені 3 обох боків та на кінці, що дало змогу воїнам завдавати не лише рубальні, а й колючі удари. Лезо виготовлене із заліза, а руків'я - зі слонової кістки, загальна довжина сягає 60 см. Подібний меч міг вдало застосовуватися в кінному бою, але був вельми малодієвим проти піхоти. Напевне, через таку особливість озброєння легка африканська кавалерія та піхота часто діяли спільно. У похованнях на території нумідійських племен, що належать до періоду Пунічних війн, археологами знайдені бронзові кавалерійські мечі особливого типу: серпоподібної форми, загострені лише з одного боку, споряджені прямим руків'ям. Їхня загальна довжина сягала 55 см. Ці берберські мечі були ефективні для раптових нальотів та рейдів. Можливо, саме тому Баркіди використовували берберів переважно як розвідників.

Згідно зі Страбоном, зі всієї кінської збруї нумідійці користувалися лише мотузковою вуздечкою та лляним ошийником (Strab., XV.4.8), що доволі правдоподібно, враховуючи спосіб ведення бою кочовиків. Із другого боку, у Фронтіна міститься свідчення про наявність в африканських вершників стремен, які вони надягали для деяких битв (Front., I.5.16).

Отже, можна стверджувати, що завдяки своєму комплекту озброєння та професійній підготовці африканська кіннота була доволі універсальним видом військ. Карфагеняни використовували іiі для розвідки, фуражування, виснаження противника й завдавання удару у вирішальні моменти бою. Жодна військова кампанія Баркідів не обходилась без участі цих вершників, які, попри поширену думку, були не класичними найманцями, а пов'язувалися зі своїми полководцями особистою вірністю.

\section{ЛІТЕРАТУРА}

Алексинский Д., Жуков К., Бутягин А., Коровкин Д. Всадники войны. Кавалерия Европы. Москва, 2005.

Андерсон Дж. Древнегреческая конница. Санкт-Петербург, 2006.

Денисон Дж. История конницы. Москва, 2001.

Козак А. Особливості військового мистецтва кавалерії та елефантерії армії Баркідів (241-202 pр. до н. е. // Питання стародавньої та середньовічної історії, археології й етнології. 2010. Т. 2 (30).

Конноли П. Греция и Рим. Энциклопедия военной истории. Москва, 2001.

Лансель С. Ганнибал. Москва, 2002.

Циркин Ю. От Ханаана до Карфагена. Москва, 2001.

Bagnall N. The Punic wars. London, 1991.

Bradford A. With arrow, sword, and spear: A history of warfare in the ancient world. London, 2001.

Brett M., Fentress E. The Berbers. Oxford, 1996.

Daily G. Cannae. The experience of battle in the Second Punic War. London, 2008.

Fields N. Hannibal. London, 2011.

Fuchs J. Der zweite punische Krieg und seine Quellen. Winen, 1894.

Griffith $G$. The Mercenaries of the Hellenistic World. Cambridge, 1935. 
Gsell S. Histoire ancienne de l'Afrique du Nord. T. 3. Histoire militaire de Carthage. Paris, 1928.

Head D. Armies of the Macedonian and Punic Wars 359 BC to 146 BC. London, 1982.

Healy M. Cannae 216 BC: Hannibal smashes Rome's Army. London, 1994.

Hoyos D. The Carthaginians. London, 2010.

Hoyos D. Carthage's Other Wars: Carthaginian Warfare Outside the 'Punic Wars' Against Rome. London, 2019.

Hyland A. Equus: The Horse in the Roman World. New Haven, 1990.

Lazenby J. Hannibal's war: A military history of the Second Punic War. Warminster, 1978 .

Lazenby J. The First Punic War: A military history. Stanford, 1996.

Lopez-Sanchez F. Numidian Kings and Numidian Garrisons during the Second Punic War: Coins and History // Potestas. Estudios del Mundo Clásico e Historia del Arte. 2010. No. 3.

Salmon E. The Strategy of the Second Punic War// Greece and Rome. Second Series. 1960 . Vol. 7, No. 2.

Snodgrass A. Arms and Armor of the Greeks. Baltimore, 1997.

Walbank F. A Historical Commentary on Polybius. Vol. 1. Oxford, 1957.

Walsh P. Massinissa // The Journal of Roman Studies. 1965. Vol. 55, No. 1-2.

Warmington B. Carthage. London, 1964.

\section{REFERENCES}

Aleksinskij D., Zhukov K., Butyagin A. and Korovkin D. (2005), Vsadniki vojny. Kavaleriya Evropy, AST, Moscow. (In Russian).

Anderson Dzh. (2006), Drevnegrecheskaya konnica, Izd-vo S.-Peterburzhskogo unta, Saint Petersburg. (In Russian).

Denison Dzh. (2001), Istoriya konnicy, AST, Moscow. (In Russian).

Kozak A. I. (2010), "Osoblyvosti vijs'kovogo mistectva kavalerii ta elefanterii armii Barkidiv (241-202 rr. do n. e.)", Pytannya starodavn'oï ta seredn'ovichnoi istorii, arheologii i etnologii, Vol. 2 (30), pp. 254-69. (In Ukrainian).

Konnoli P. (2001), Greciya i Rim. Enciklopediya voennoj istorii, EKSMO, Moscow. (In Russian).

Lansel C. (2002), Hannibal, Molodaya Gvardiya, Moscow. (In Russian).

Tsirkin Y. U. (2001), Ot Hanaana do Karfagena, AST, Moscow. (In Russian).

Bagnall N. (1991), The Punic Wars, Hutchinson, London.

Bradford A. (2001), With Arrow, Sword, and Spear: A History of Warfare in the Ancient World, Praeger Publishers, London.

Brett M. and Fentress E. (1996), The Berbers, Blackwell, Oxford.

Daily G. (2008), Cannae. The experience of battle in the Second Punic War, Routledge, London.

Fields N. (2011), Hannibal, Osprey Publishing, London.

Fuchs J. (1894), Der zweite punische Krieg und seine Quellen, Blumrich, Winen.

Griffith G. (1935), The Mercenaries of the Hellenistic World, Cambridge University Press, Cambridge. 
Роль африканської кавалерії в армії Баркідів

Gsell S. (1928), Histoire ancienne de l'Afrique du Nord, T. 3. Histoire militaire de Carthage, Librairie Hachette, Paris.

Head D. (1982), Armies of the Macedonian and Punic Wars 359 BC to 146 BC, War games Group, London.

Healy M. (1994), Cannae 216 BC: Hannibal smashes Rome's Army, Osprey Publishing, London.

Hoyos D. (2010), The Carthaginians, Routledge, London.

Hoyos D. (2019), Carthage's Other Wars: Carthaginian Warfare Outside the 'Punic Wars' Against Rome, Pen \& Sword Military, London.

Hyland A. (1990), Equus: The Horse in the Roman World, Yale University Press, New Haven.

Lazenby J. (1978), Hannibal's war: A military history of the Second Punic War, Aris and Philips, Warminster.

Lazenby J. (1996), The First Punic War: A military history, Stanford University Press, Stanford.

Lopez-Sanchez F. (2010), "Numidian Kings and Numidian Garrisons during the Second Punic War: Coins and History", Potestas. Estudios del Mundo Clásico e Historia del Arte, No. 3, pp. 17-52.

Salmon E. (1960), "The Strategy of the Second Punic War", Greece and Rome. Second Series, Vol. 7, No. 2, pp. 131-42.

Snodgrass A. (1997), Arms and Armor of the Greeks, The Johns Hopkins University Press, Baltimore.

Walbank F. (1957), A Historical Commentary on Polybius, Vol. 1, Oxford University Press, Oxford.

Walsh P. (1965), "Massinissa”, The Journal of Roman Studies, Vol. 55, No. 1-2, pp. 149-60.

Warmington B. (1964), Carthage, Penguin, London.

$$
\text { A. I. Козак }
$$

РОЛЯ АФРЫКАНСКАЙ КАВАЛЕРЫІ Ў АРМІІ БАРКІДАЎ

У артыкуле аналізуюцца кавалерыйскія атрады, якія складаліся з жыхароў Афрыкі (лівафінікійцаў і нумідыйцаў), як непасрэдна 3 падданых Карфагена, так і з саюзных пунійцам плямёнаў, прадстаўляючы ядро арміі Баркідаў у час Другой Пунічнай вайны (218201 гг. да н. э.) і адыгралі рашучую ролю ў большасці буйных сражэнняў. Разглядаюцца такія аспекты, як тактыка, узбраенне, статус вершнікаў, звязаныя са згаданымі ваеннымі фарміраваннямі. Пацверджана, што, нягледзячы на распаўсюджаны стэрэатыпу пра нумідыйцаў і лівафінікійцаў як наёмнікаў, яны ваявалі на добраахвотнай аснове. 3 аднаго боку, гэта забяспечвала ім высокі дух і матывацыю, а 3 другога - яны, як і любое апалчэнне, дзейнічалі толькі паблізу тэрыторыі свайго рассялення, і толькі ў невялікай колькасці адпраўляліся ў працяглыя ваенныя паходы. Надаецца ўвага асаблівасцям узбраення афрыканскай конніцы. У лівафінікійцаў гэта была эліністычная манера з кальчугаю ці кірасаю, дзідай і шчытом. Нумідыйцы выкарыстоўвалі хітоны і скураныя панцыры, паверх якіх надзявалі плашчы, і цюрэасы - круглыя скураныя шчыты сярэдняга памеру. Галоўнай наступальнай зброяй нумідыйцаў былі дротыкі, цалкам зробленыя з дрэва, 3 жалезнымі лаўравіднымі наканечнікамі. Даказываецца, што дзякуючы свайму камплекту ўзбраення і прафесійнай падрыхтоўке, афрыканская конніца стала дастаткова ўніверсальным відам войска. Карфагеняне выкарыстоўвалі яе для разведкі, фуражыроўкі, знясілення праціўніка і нанясення ўдараў у вырашальны момант боя. Ні адна ваенная кампанія Баркідаў не абыходзілася без 


\section{А. І. Козак}

удзелу гэтых вершнікаў, якія, нягледзячы на распаўсюджанае меркаванне, былі не класічнымі наёмнікамі, а звязваліся са сваімі палкаводцамі асабістай вернасцю.

Ключавыя словы: Карфаген, Другая пунічная вайна, Ганібал, нумідыйцы, лівафінікійцы, элінізм, ваеннае мастацтва, узбраенне, тактыка

\section{A. I. Козак \\ РОЛЬ АФРИКАНСЬКОЇ КАВАЛЕРІЇ В АРМІЇ БАРКІДІВ}

У статті аналізуються кавалерійські загони, щодо складалися з жителів Африки (лівофінікійці і нумідійців), як безпосередньо $з$ підданих Карфагена, так і з союзних пунійцям племен, становили ядро армії Баркідів під час Другої Пунічної війни (218-201 рр. до н. е.) й відіграли вирішальну роль у більшості визначних битв. Розглядаються такі аспекти, як тактика, озброєння, статус вершників, пов'язаних зі згаданими військовими формуваннями. Стверджується, що, незважаючи на поширений стереотип щодо нумідійців і лівофінікійців як найманців, вони воювали на добровільних засадах. 3 одного боку, це забезпечувало їм високий бойовий дух та мотивацію, а 3 другого - вони, як і будь-яке ополчення, діяли тільки поблизу територій свого розселення, лише в невеликій кількості вирушаючи у тривалі воєнні походи. Приділяється увага особливостям озброєння африканської кінноти. У лівофінікійців це була елліністична манера 3 кольчугою або кірасою, списом та щитом. Нумідійці використовували хітони та шкіряні панцирі, поверх яких надягали плащі, та тюреоси - круглі шкіряні щити середнього розміру. Головною наступальною зброєю нумідійців були дротики, цілковито виготовлені $з$ дерева, із залізними лавроподібними наконечниками. Доводиться, що завдяки своєму комплекту озброєння та професійній підготовці африканська кіннота була досить універсальним видом військ. Карфагеняни використовували їі для розвідки, фуражування, виснаження противника й завдавання удару у вирішальні моменти бою. Жодна воєнна кампанія Баркідів не обходилась без участі цих вершників, які, попри поширену думку, були не класичними найманцями, а пов'язувалися зі своїми полководцями особистою вірністю.

Ключові слова: Карфаген, Друга Пунічна війна, Ганнібал, нумідійці, лівофінікійці, еллінізм, військове мистецтво, озброєння, тактика 